\title{
International Integration and Coordination in MNEs
}

\section{Implications for International Management}

\author{
Rudolf R. Sinkovics $\cdot$ Anthony S. Roath $\cdot$ S. Tamer Cavusgil
}

\begin{abstract}
:
- The focus theme "International integration and coordination in MNEs - Implications for international management" is introduced and the motivation for this focus issue theme is outlined. The premise of the theme is the notion that the nature of organizational response to heightened global dynamism has changed. It is argued that the managerial mechanisms or "tools" necessary to accomplish coordination tasks have changed accordingly.

- The manuscripts included in this focused issue capture this perspective building conceptual and empirical contributions. These include cross-border knowledge transfer, global strategy implementation, IT integration as enabler of MNE-supplier responsiveness, intra-firm architectural network configuration, regional integration perspectives from Latin America and integration and coordination in the global factory.
\end{abstract}

Keywords: International integration · Coordination · MNE structures

Published online: 02.04.2011

(C) Gabler-Verlag 2011

Prof. R. R. Sinkovics $(\square)$

Manchester Business School, University of Manchester,

Manchester, United Kingdom

e-mail: Rudolf.Sinkovics@manchester.ac.uk

Assoc. Prof. A. S. Roath

Department of Marketing \& Supply Chain Management, University of Oklahoma, Oklahoma City, USA

Prof. S. T. Cavusgil

Institute of International Business, Georgia State University,

Atlanta, USA 


\section{Introduction to the Focused Issue}

Traditionally, multinational enterprises (MNEs) have developed structures that resembled federative rather than unitary organizations (Yamin and Forsgren 2006), implying that a significant degree of autonomy was retained for nationally focused subsidiaries (Birkinshaw and Hood 2000). However, globalization forces and environmental transformations, including increasing market liberalization and advances in information and communication technologies (Jean et al. 2010; Yamin and Sinkovics 2007, 2010), have challenged traditional international business strategy and structure (Lin et al. 2009; Peng et al. 2009). Indeed, the need to access scarce resources has heightened uncertainty and risks, inciting the interest to understand how the structure of international business complements strategy. As global value chains evolve (Kotabe and Mudambi 2009), the foundation upon which to achieve global integration of strategic and operational activities (Buckley and Ghauri 2004) has provoked great attention to managerial decision making. This approach to better understand the rapidly changing nature of risk and uncertainty is reflected in the gradual return to company headquarters or regional centers (Rugman 2005).

The premise of this focused issue is that the nature of organizational response to heightened global dynamism and the managerial mechanisms or "tools" necessary to accomplish coordination tasks have changed. Not only do we witness reconfiguration within firms and organizations, but these changes are extending to inter-firm relationships, highlighting the need to configure and coordinate geographically dispersed networks (e.g. Kotabe and Mudambi 2009; Liu et al. 2010). For example, organizations in global networks are developing capabilities that enable faster response, deeper integration from enhanced technology, better information flows through process improvements, and a broader awareness of their environment through geopolitical involvement. Some illustrations include the increasing adoption of mechanisms such as global account management (Shi et al. 2010), and global brand teams and product innovation management mechanisms (Townsend et al. 2010). Consequently, the implementation of these management tools has created a fascinating evolution in the redefinition of firm boundaries, evident in the restructuring of the global supply (value) chain (Buckley and Ghauri 2004), the management of ambiguous boundaries such as in outsourcing (Hätönen and Eriksson 2009), and a redefinition of headquarter power. To capture the essence of this trend succinctly, Yamin and Forsgren (2006) refer to these effects as the 'demise of the federative MNE'.

The dynamics of this phenomenon and their fascinating implications to multinational structures and management have motivated this focus issues and triggered substantial interest from the academic community. Out of more than thirty submissions, the call for papers yielded seven illuminating papers which highlight the varied nature of an evolving global network of organizations and how they respond to the challenges associated with their ability to deal with uncertainty. In particular, these papers address a number of functional areas and associated management mechanisms ('tools') that help to facilitate the integration and coordination within and among the increasingly complex nature of MNEs. The authors explore conceptual and empirical approaches in global supply chain management, IT platforms, and organizational integration and coordination within the global environment. 


\section{Papers Included in the Focused Issue}

Arguably, a motivation for the emergence of these evolving infrastructures and strategies is based on the realization of ever more scarce resources. An overview of the authors' contributions illustrates the rich and varied thinking associated with examining how MNEs deal with scarce resources. It is not only the notion of access to resources, but the idea of utilizing these resources productively. Knowledge provides a surrogate for resource sustainability; an approach to utilize knowledge as a 'tool' and a way to ensure organizations possess a "sustained" resource. Indeed, the papers included in this issue examine how international companies, within their respective global networks, confront and embrace the challenges of contemporary, dynamic global markets. The development of information technology certainly has helped to generate greater awareness of knowledge and the need to develop an ability to ensure efficient knowledge transfer mechanisms among the organizations (Roberts 2009). As is subsumed within the manuscripts, knowledge underlies a fundamental tension with the relationship between the MNE headquarters and its subsidiaries. Knowledge is employed as a governance method for control as well as a tool to enhance the efficiency of the global network. The paradox provides a direct obstacle to achieving competitive advantage, yet knowledge also serves as a "sustainable resource" and a foundation upon which to develop a sustainable competitive advantage.

The special issue begins with an examination of the role of knowledge transfer among cross border organizations, which is acknowledged in the international business literature as a vital element to global success (Peng and Pleggenkuhle-Miles 2009). Specifically, Ciabuschi, Dellestrand and Kappen explore the effects of transfer mechanisms (hierarchy, heterarchy and IT) on knowledge transfer success; essentially they study the efficiency and effectiveness of the transfer project illustrated by knowledge transfer. The important point is how the centralization of knowledge transfer through headquarters' involvement negatively influences both the efficiency and effectiveness of the knowledge transferred among organizations. Contrarily, cooperation between subsidiaries leads to more effective knowledge transfer but it is not efficient. These outcomes have many implications on the vertical or lateral structure of the organizations and this structure's effect on knowledge transfer.

Yamin, Tsai, and Holm follow the theme of knowledge and its role in the network via a study that explores how knowledge is transferred through lateral-oriented structures. The dilemma which headquarter management faces, is that the network structure typifying many MNCs has beneficial impacts on the performance of the transfer process. At the same time, HQ needs to ensure that lateral transfers initiated by subsidiaries ('organic' transfers) are in line with overall MNC strategy. In other words, there seems to be a delicate balance between direct HQ involvement, which yields benefits while ensuring strategic goals are met, and the presupposition that subsidiaries must also have a large degree of autonomy with how they transfer knowledge in order for the overall structure to be effective. Unfortunately, HQ direct involvement does not seem to be the best approach to ensuring an efficient transfer process.

The empirical study examines this dilemma by investigating the implications of the direct effects of resource (including knowledge) implications of headquarters' participation in the transfer process as well as the indirect effects of headquarters' involvement in 
transfer among subsidiaries; the latter investigates the moderating effects of the attributes of transfer relationships. Similar to the first paper, they explore the efficiency and effectiveness of the transfer process. Some key findings emerge from the study. One of them is that the direct effect of HQ involvement in lateral transfer impairs efficiency without clear gains in transfer effectiveness. Indeed, HQ involvement in the transfer between subsidiaries seems to disrupt or decrease the willingness of the subsidiaries to work together.

This paper complements well Ciabuschi, Dellestrand and Kappen's study on the effects of knowledge transfer mechanisms. Both of these contributions point to the potentially negative implications of HQ involvement in knowledge transfer throughout the network structure. Whereas, both papers suggest that HQ involvement may impede efficient knowledge transfer among organizations, Yamin, Tsai and Holm advance this idea by highlighting the notion that HQ involvement also negatively impacts upon the willingness of subsidiaries to work among them. The overall implication points to a definite change in network organizational structure. The challenge to the HQ is presented; its role as the primary agent to confront dynamic market changes while managing the ability to develop competitive advantages is examined in greater depth.

A subtle, yet important change in perspective from the examination of the structure is to consider how the existing organizational structures implement strategic decisions in these dynamic and complex global environments. The next three papers do not necessarily question the organizational structure itself; rather they consider the actual organizational structure and implementation in order to examine how the organizations integrate and coordinate more efficiently. Yaprak, $\mathrm{Xu}$, and Cavusgil work towards outlining the structure and processes that MNEs require to successfully implement global strategy. Accordingly, the authors investigate how MNEs integrate and coordinate their activities across global markets to determine whether their efforts increase efficiency and effectiveness. This paper is based on the premise that MNEs' develop capabilities, reflected in process mechanisms, to enhance the efficiency and effectiveness of global operations.

Sinkovics, Jean, Roath and Cavusgil suggest that in order to enhance local suppliers' responsiveness in global supply chain relationships, MNEs must work with their local suppliers to create new forms of relationship structures. They argue that cultural and country differences influence and to some extent limit the use and effectiveness of traditional tools that govern the relationships between MNE and their local suppliers. By drawing on a database of Taiwanese electronics suppliers, the scholars demonstrate that the use of IT integration - via information technology and trust-helps to enhance local suppliers' responsiveness (seen as a capability) in global supply chain relationships.

The idea of integration within the existing network is captured by Keupp, Palmié, and Gassman in their empirical study of how the parent firm of the multinational corporation confronts challenges to its role as the dominant change agent. This study articulates the utilization of managerial "tools" to manipulate the formal organizational architecture. The parent firm integrates its subsidiaries by granting them a high degree of autonomy and a mandate to contribute to the corporation as a whole. The primary 'tool' that facilitates integration is knowledge transfer. Their findings motivates spirited dialog into the concepts of integration, collaboration and the important role of knowledge.

De la Torre, Esperanca and Martinez investigate the influence of the Latin American market upon multinational companies and their response. Their survey of MNEs reveals 
that the organizations sought greater coordination of regional operations the decade, as expected, but not along all dimensions and not always proportionally to the changes perceived by their managers. The linkages between different dimensions of perceived market integration and organizational responses are largely significant and are consistent with contingency theory.

The final two papers suggest possibilities that highlight the evolution of the multinational enterprise and its implications in the global economy. Peter Buckley points to a new institutional form that aptly can be seen as a renewed conceptualization of earlier manuscripts in this focus issue.

Buckley proposes that the new institutional form known as "the global factory" is key to understanding changes in the configuration of the world economy. The evolution of the global factory requires managers to act as orchestrators or coordinators across the system of globally inter-connected firms. Managerial styles need to accommodate these changes, which imply that integration and coordination in the global factory are now critical factors to achieve success. Arguably, the control of information is central and seems to be the most common and consistent factor underlying organizational changes and implementation across the global network. Location and control are still key variables but extra degrees of freedom in location of activities and non-ownership forms of control are increasing in importance. Again, Buckley highlights the importance of knowledge and its transfer among international organizations as a major force that challenges and manipulates organizational structures as well as the conduct of strategy and operations.

The final paper by Mo Yamin is a commentary on Peter Buckley's contribution on the global factory. Yamin reviews earlier work by Buckley on the global factory and provides specific comments regarding the paper included in this focused issue. He suggests that the idea of control over the organization and its environment through knowledge from the global factory must be tempered. He points to potential vulnerabilities associated with the global factory's dependence upon a governance regime which supports it. Yamin's argument is that the organization cannot extract power solely from within, but must also rely upon political elements that are inherent in each market environment. This issue is also addressed in the paper by de la Torre et al., who suggest this idea as they investigate multinational organizations' responses to the evolving Latin American market. Yamin's commentary not only helps in the understanding of Buckley's global factory contribution on international business, but also has significant ramifications regarding strategic directions which IB scholarship could or even should open. Yamin concludes that Buckley's Global Factory writings can be seen as a suggestion that the IB research agenda is not running out of steam, rather, by adopting or "injecting" insights from neighbouring disciplines (e.g. economic geography, global value chain, political economy and economic development), the IB research agenda may find rejuvenating and fruitful inspiration. Certainly, the phenomenon teases the notion of revolutions in examining innovative business structures and governance arrangements.

Acknowledgments: Special thanks go to the editors of Management International Review, Michael-Jörg Oesterle and Joachim Wolf, whose support of this initiative has helped to make this project happen. Furthermore, we are indebted to colleagues who were prepared to invest time and effort to review the papers submitted to this focused issue. Their contribution has been 
vital to the development of the papers and to the overall coherence of this special volume. The reviewers are listed in alphabetical order.

M. Billur Akdeniz, University of New Hampshire, USA

Eva Alfoldi, Manchester Business School, UK

Vassiliki Bamiatzi, Leeds University, UK

Nigel Barrett, University of Technology Sydney, Australia

Haozhe Chen, East Carolina University, USA

Adam Cross, Leeds University, UK

Laszlo Czaban, Manchester Business School, UK

Z. Seyda Deligonul, St. John Fisher College, USA

Mats Forsgren, Uppsala University, Sweden

Hanna Gajewska-DeMattos, Leeds University, UK

Pervez N. Ghauri, King's College London, UK

Simon Harris, Edinburgh University, UK

Liza Jabbour, University of Birmingham, UK

Ruey-Jer Bryan Jean, National Chengchi University, Taiwan

Daekwan Kim, Florida State University, USA

Olli Kuivalainen, Lappeenranta University of Technology, Finland

Peter Liesch, University of Queensland, Australia

Chia-Ling "Eunice" Liu, National Cheng Kung University, Taiwan

Sharon Loane, University of Ulster, Ireland

Silvia Massini, Manchester Business School, UK

Frank McDonald, University of Bradford, UK

Alexander T. Mohr, University of Kent, UK

Trevor Morrow, University of Ulster, Ireland

Matthew B. Myers, University of Tennessee, USA

Pieter Pauwels, Maastricht University, The Netherlands

Bob Pearce, University of Reading, UK

Konstantinos Poulis, University of Essex, UK

Anthony S. Roath, Oklahoma University, USA

Alan Rugman, University of Reading, UK

Arnold Schuh, Wirtschaftsuniversität Vienna, Austria

Carl Arthur Solberg, BI Norwegian School of Management, Norway

Roger Strange, University of Sussex, UK

Mehmet Berk Talay, HEC Montréal, Canada

Janell Townsend, Oakland University, USA

Heinz Josef Tüselman, Manchester Metropolitan University, UK

Mo Yamin, Manchester Business School, UK

Sengun Yeniyurt, Rutgers University, USA

Stefan Zagelmeyer, FH Bad Honeff, Germany

Chun Zhang, University of Vermont, USA

Huan 'Joy' Zou, University of London SOAS, UK

Shaoming Zou, University of Missouri, USA

Anna Zueva, University of Bradford, UK.

\section{References}

Birkinshaw, J., \& Hood, N. (2000). Characteristics of foreign subsidiaries in industry clusters. Journal of International Business Studies, 31(1), 141-154. 
Buckley, P. J., \& Ghauri, P. N. (2004). Globalisation, economic geography and the strategy of multinational enterprises. Journal of International Business Studies, 35(2), 81-98.

Hätönen, J., \& Eriksson, T. (2009). 30+ years of research and practice of outsourcing-Exploring the past and anticipating the future. Journal of International Management, 15(2), 142-155.

Jean, R.-J. B., Sinkovics, R. R., \& Cavusgil, S. T. (2010). Enhancing international customer-supplier relationships through IT resources: A study of Taiwanese electronics suppliers. Journal of International Business Studies, 41(7), 1218-1239.

Kotabe, M., \& Mudambi, R. (2009). Global sourcing and value creation: Opportunities and challenges. Journal of International Management, 15(2), 121-125.

Lin, Z., Peng, M. W., Yang, H., \& Sun, S. L. (2009). How do networks and learning drive M\&As? An institutional comparison between China and the United States. Strategic Management Journal, 30(10), 1113-1132.

Liu, C.-L. E., Ghauri, P. N., \& Sinkovics, R. R. (2010). Understanding the impact of relational capital and organizational learning on alliance outcomes. Journal of World Business, 45(3), 237-249.

Peng, M. W., \& Pleggenkuhle-Miles, E. G. (2009). Current debates in global strategy. International Journal of Management Reviews, 11(1), 51-68.

Peng, M. W., Sunny Li, S., Pinkham, B., \& Hao, C. (2009). The institution-based view as a third leg for a strategy tripod. Academy of Management Perspectives, 23(3), 63-81.

Roberts, J. (2009). The global knowledge economy in question. Critical Perspectives on International Business, 5(4), 285-303.

Rugman, A. M. (2005). The regional multinationals: MNEs and "global" strategic management. Cambridge: Cambridge University Press.

Shi, L. H., White, J. C., Zou, S., \& Cavusgil, S. T. (2010). Global account management strategies: Drivers and outcomes. Journal of International Business Studies, 41(4), 620-638.

Townsend, J. D., Cavusgil, S. T., \& Baba, M. L. (2010). Global integration of brands and new product development at general motors. Journal of Product Innovation Management, 27(1), 49-65.

Yamin, M., \& Forsgren, M. (2006). Hymer's analysis of the multinational organization: Power retention and the demise of the federative MNE. International Business Review, 15(2), 166-179.

Yamin, M., \& Sinkovics, R. R. (2007). ICT and MNE reorganisation: The paradox of control. Critical Perspectives on International Business, 3(4), 322-336.

Yamin, M., \& Sinkovics, R. R. (2010). ICT deployment and resource-based power in multinational enterprises. Futures, 42(9), 952-959. 